\title{
Effect of Soil Management Practices on the Mineralization of Organic Matter and Quality of Sandy Soils
}

\author{
Mirosław Kobierski ${ }^{1 *}$, Bogumiła Cieścińska ${ }^{1}$, Jacek Cieściński², \\ Krystyna Kondratowicz-Maciejewska'
}

1 UTP University of Science and Technology, Department of Biogeochemistry and Soil Science, ul. Bernardyńska 6, 85-029 Bydgoszcz, Poland

2 UTP University of Science and Technology, Department of Environmental Engineering, ul. Sucha 9, Bydgoszcz, Poland

* Corresponding author's e-mail: kobierski@utp.edu.pl

\begin{abstract}
The aim of the study was to determine the effect of soil management systems of Brunic Arenosols on the total content of organic carbon and its fraction susceptible to oxidation in comparison with the soils under forests. The samples for study were taken from the humus horizon at the sites located in the forests and soils from little midforest cultivated fields (hunting plots). The agrotechnical treatments increased the content of the plant-available forms of $\mathrm{P}, \mathrm{K}$ and $\mathrm{Mg}$ in the soils of most hunting plots in comparison to the forest soils. In the arable horizon of the hunting plots, $\mathrm{t}$ a varied total content of organic carbon and its fraction susceptible to oxidation was found. The cultivation of soil in the hunting plots caused a decrease in the content of total organic carbon as well as its labile and non-labile fraction. In order to evaluate the carbon transformation in the soil of the cultivated plots against the forest (reference soil), the Carbon Management Index (CMI) was used. The decay rate of soil organic matter in a natural forest was lower than in the agricultural fields. A long-term tillage of Brunic Arenosols contributed to the degradation of the pool of organic carbon in sandy-textured soil.
\end{abstract}

Keywords: soil organic carbon, Carbon Management Index, macronutrients

\section{INTRODUCTION}

Soil organic matter (SOM) from the forest soils is found at various stages of decomposition as well as processing and remains the main source of organic carbon fractions and acts as an important store and source of plant nutrients [Gałka and Łabaz 2014]. Humus is the stable fraction of SOM and the methods for the separation and analysis of these fractions are therefore required [Skjemstad et al. 2006]. The forest soils usually have higher SOM than the arable soils. The accumulation of SOM in low-productivity soils depends on the land use intensity and agrotechnical operations, fertilisation as well as the removal of biomass [Kazlauskaite-Jadzevice et al. 2019]. Even limited agrotechnical treatments affect the soil properties. Soil tillage is one of the main agrotechnical operations because of its influence on the physical, chemical and biological properties of soil [Halpern et al. 2010, van Eerd et al. 2014, Stanek-Tarkowska et al. 2018]. Murty et al. [2002] pointed out that the conversion of forest to uncultivated grazing land did not, on average, lead to a decrease in the content of SOM, although individual areas may lose or gain soil organic carbon (SOC), depending on the fertilization applied, water retention or plant residues. The evaluation of those processes should be based not only on the current content of SOC but also on the forecast SOM transformations, especially in terms of the rate of its mineralization. An ability to detect the SOC change as a result of landuse or management change is important to allow making decisions to mitigate the fertility decline. Among the methods which give possibility for 
assessment the susceptibility to chemical oxidation of SOC, the method with a solution of potassium permanganate VII was use [Łoginow et al. 1987]. The modification and standardization of this method [Blair et al. 1995, Lefroy 1993] allows determining the content of labile carbon $\left(\mathrm{C}_{\mathrm{L}}\right)$ and non-labile carbon $\left(\mathrm{C}_{\mathrm{NL}}\right)$ of SOM [Skjemstad et al. 2006]. The content of $C_{L}$ can provide a considerable indicator of SOC transformations in soil [Conteh et al. 1999]. Considering the interactions between $\mathrm{C}_{\text {org }}, \mathrm{C}_{\mathrm{L}}$ and $\mathrm{C}_{\mathrm{NL}}$, one can determine the following: Lability Index (LI), Carbon Pool Size Index (CPI) and Carbon Management Index (CMI) in soil. On the basis of those indices it is possible to evaluate the SOC management as a measure of relative permanence of various methods of soil use. In the studies on SOC in cultivated soils, the obtained results are referred to the reference objects. These are usually non-cultivated soils, forest soils, pastures [Blair et al. 1995, Blair et al. 1997, Szombathova 1999], as well as urban soils [Vaseneva et al. 2013]. Szombathova [1999] compared the forest soil with the soils under organic and integrated farming using CMI, CPI, LI. She also demonstrated that the total organic carbon content in the forest soil was almost threefold higher than in the arable soils and the values of LI in the soil under organic farming were higher than in the forest soil. Strączyńska et al. [2009] showed that in the ectohumus under the plantings of black locust, the values of CPI and CMI are more favourable than under the trees of Scots pine. The soil studies of the static fertilisation experiment exposed to long-term agrotechnical treatments showed the applicability of these indices to the evaluation of the effect of the type of fertilisation on the organic carbon management in soil [Cieścińska 2007a,b].

The aim of the present research was to compare the content of SOC and its fraction susceptible to oxidation in the arable horizon of the cultivated (hunting) plots and the humus horizon of the soils under forest.

\section{MATERIALS AND METHODS}

The research material was made up of the samples of forest soils taken in the area of the Szubin Forest Division, in the Kujawsko-pomorskie Province, in Poland. The forests stand composition is dominated by pine which found perfect development conditions in those habitats. Other species include: spruce, beech, oak, ash tree, birch, alder, larch, aspen, and hornbeam tree. The humus horizon was only a few centimetres thick (from 7.0 to $10.0 \mathrm{~cm}$ ). The cultivation of soil in the hunting plots located inside the forests aims at supplementing and enhancing the feeding conditions of forest animals. The selection of the plant species grown can considerably enrich the feeding base for the forest animals. Due to the dominant effect of woody plants on a relatively small area of the hunting plots, these soils can be also considered as forest soils. The cultivated plots area varied from 0.9 to 2.4 ha. The plots were exposed to basic agrotechnical treatments, including mineral fertilisation. The soil samples were taken from the arable horizon (Ap) of eight cultivated hunting plots and from the humus horizon (A) under four forests (references samples F1-4). The arable soil sampling sites were selected randomly in the middle part of the cultivated plots. The averaged samples of the soils of the plots and under forests were made from three individual samples. The collected soil samples were dried and sieved through a $2-\mathrm{mm}$ sieve. The following parameters were determined in the soil samples:

a) grain size composition - using the areometric and sieve method,

b) $\mathrm{pH} w 1 \mathrm{M} \mathrm{KCl}$ and $\mathrm{pH}$ in $\mathrm{H}_{2} \mathrm{O}_{\text {dest. }}$ - potentiometric method,

c) hydrolytic acidity - according to the Kappen method (the air-dried soil samples were treated in the solution of sodium acetate),

d) exchangeable cations according to the method with $0.1 \mathrm{M} \mathrm{BaCl}_{2}$ solution (the content of cations was measured by AAS apparatus PHILIPS PU 9100X),

e) $\mathrm{C}_{\text {org }}$ and total nitrogen $\left(\mathrm{N}_{\mathrm{T}}\right)$ Vario Max CN-Elementar Analysensystem $\mathrm{GmbH}$ analyzer,

f) content of the available forms of phosphorus $\left(\mathrm{P}_{2} \mathrm{O}_{5}\right)$ and potassium $\left(\mathrm{K}_{2} \mathrm{O}\right)$ with the EgnerRiehm method (pH 3.6, $0.02 \mathrm{~mol} / \mathrm{L}$ hydrochloric acid and $0.04 \mathrm{~mol} / \mathrm{L}$ calcium lactate, soil:solution ratio $1: 50$ ), as well as the content of $\mathrm{Mg}$ available to plants following the Schachtschabel method $\left(0.0125 \mathrm{~mol} / \mathrm{L} \mathrm{CaCl}_{2}\right.$ with soil:solution ratio 1:10. Phosphorus was determined with the Genesis 6 spectrophotometer (Madison, USA), potassium and magnesium - using atomic absorption spectrometry (AAS, Philips 9100, Cambridge, UK). 
The oxidation of organic carbon with potassium permanganate VII $\left(333 \mathrm{mmol} / \mathrm{dm}^{3}\right)$ in neutral environment was prepared according to a method devised by Łoginow et al. [1987].

The calculations considered the following:

- L (lability of carbon) $=$ having determined the Corg, the soils were exposed to chemical oxidation. In the soil samples of the hunting plots and the reference soil samples (from forests) the contents of labile fraction (CL) and nonlabile fraction $(\mathrm{CNL})$ of carbon were assayed. The fractions determined that way were used to determine Carbon Management Index (CMI), Carbon Pool Size Index (CPI) and Lability Index (LI) according to Blair et al. [1997]. Corg oxidised by $\mathrm{KMnO}_{4} /$ Corg remaining unoxidised by $\mathrm{KMnO}_{4}$;

- $\mathrm{L}=\mathrm{CL} / \mathrm{CNL}$;

- LI (Corg lability idicator) $=\mathrm{L}$ in cultivated soil $/ \mathrm{L}$ in reference soil $\times 100 \%$;

- $\mathrm{CPI}=$ Corg in cultivated soil $(\mathrm{g} / \mathrm{kg}) /$ Corg in reference soil $(\mathrm{g} / \mathrm{kg})$;

- $\mathrm{CMI}=\mathrm{CPI} \times \mathrm{LI}$.

Compliant with the concept by Blair et al. [1995], the reference soil should be the control in which the dynamics of changes in the content of carbon is conditioned by the natural processes or similar to the natural ones. The reference soils in this experiment was made up of the averaged sample from the forests (F1-4) surrounding the plots investigated.

The soil properties were treated with standard statistics and statistical tests (ANOVA). The statistical analyses were made using Statistica 10.0 (StatSoft Inc, Tulsa, USA). The significance of the differences between means was evaluated drawing on the Tukey test for uneven number. The results of the analyses were also verified statistically applying according to the WARD's method.

\section{RESULTS AND DISCUSSION}

The soils investigated in the surface horizon showed the grain size composition of fine loamy sand, except for the samples E, S2 and W2 - the grain size composition of fine sand (Table 1). Brunic Arenosols showed a strong acid reaction. The lowest values of exchangeable acidity were noted for the soils under forests (Table 2). The acidic $\mathrm{pH}$ of forest soils must have been due to the decay of pine needles which are the main component of the plant litter. Strong acidic $\mathrm{pH}$ of the needles is characteristic for Pinus species, which can affect the soil $\mathrm{pH}$ under the tree stand [Parzych et al. 2017]. In the arable horizon of cultivated plots, higher values of $\mathrm{pH}$ were found, which could have been an effect of the agricultural use of those soils. The exchangeable acidity ranged from $\mathrm{pH} 3.67$ to 4.45 . Significantly higher values of hydrolytic acidity $(\mathrm{P}=0.018)$ and insignificantly lower values of base saturation were noted in the A horizon of soils under forests in comparison with the Ap horizon (Table 3). In the arable soils, most probably more microbiologically active, the nutrient forms were more easily available to the plants and sorption and the buffer soil properties counteracted its excessive acidification [Sapek 2009]. A slight variation in the physical and physicochemical properties of cultivated soils (Fig. 1) was confirmed by the results of cluster analysis. The agrotechnical treatments also increased the content of the plant-available forms of $\mathrm{P}, \mathrm{K}$ and

Table 1. Texture of soils

\begin{tabular}{|c|c|c|c|c|c|}
\hline \multirow{3}{*}{ Sample } & \multirow[b]{2}{*}{ Depth } & \multicolumn{3}{|c|}{ Grain size composition [\%] } & \multirow{3}{*}{$\begin{array}{c}\text { Textural } \\
\text { group }\end{array}$} \\
\hline & & $\begin{array}{c}\text { Sand } \\
2-0.05\end{array}$ & $\begin{array}{c}\text { Silt } \\
0.05-0.002\end{array}$ & $\begin{array}{c}\text { Clay } \\
<0.002\end{array}$ & \\
\hline & $(\mathrm{cm})$ & \multicolumn{3}{|c|}{$(\mathrm{mm})$} & \\
\hline Forests F1-4 & $0-19$ & 86.8 & 7.3 & 5.9 & LFS \\
\hline Field D & $0-28$ & 88.2 & 5.5 & 6.3 & LFS \\
\hline Field E & $0-28$ & 91.5 & 5.4 & 3.1 & FS \\
\hline Field $\mathrm{N}$ & $0-28$ & 87.0 & 6.1 & 6.9 & LFS \\
\hline Field S1 & $0-30$ & 87.8 & 6.9 & 5.3 & LFS \\
\hline Field S2 & $0-29$ & 91.4 & 5.9 & 2.7 & FS \\
\hline Field S3 & $0-27$ & 87.6 & 5.9 & 6.5 & LFS \\
\hline Field W1 & $0-28$ & 83.1 & 9.5 & 7.4 & LFS \\
\hline Field W2 & $0-27$ & 94.6 & 3.1 & 2.3 & FS \\
\hline
\end{tabular}

FS - fine sand; LFS - fine loamy sand 
Table 2. Selected properties of soils

\begin{tabular}{|c|c|c|c|c|c|}
\hline \multirow{2}{*}{ Sample } & \multirow{2}{*}{$\begin{array}{c}\mathrm{pH} \\
1 \mathrm{M} \mathrm{KCl}\end{array}$} & $\mathrm{Hh}$ & TEB & CEC & (V) \\
\hline & & \multicolumn{2}{|c|}{$[\mathrm{mmol} / \mathrm{kg}]$} & \multicolumn{2}{|c|}{$[\%]$} \\
\hline Forests F1-4 & $3.48( \pm 0.10)$ & $80.2( \pm 1.04)$ & $41.4( \pm 0.43)$ & 121.6 & 34.0 \\
\hline Field D & $3.98( \pm 0.03)$ & $45.7( \pm 0.55)$ & $50.6( \pm 0.51)$ & 96.3 & 52.5 \\
\hline Field E & $4.51( \pm 0.04)$ & $25.7( \pm 0.47)$ & $60.1( \pm 1.02)$ & 85.8 & 70.0 \\
\hline Field $\mathrm{N}$ & $4.11( \pm 0.08)$ & $40.5( \pm 0.47)$ & $58.4( \pm 1.01)$ & 98.9 & 59.0 \\
\hline Field S1 & $4.22( \pm 0.08)$ & $46.5( \pm 0.55)$ & $49.0( \pm 0.43)$ & 95.5 & 51.3 \\
\hline Field S2 & $4.28( \pm 0.07)$ & $38.7( \pm 0.38)$ & $54.4( \pm 0.66)$ & 93.1 & 63.0 \\
\hline Field S3 & $4.27( \pm 0.14)$ & $34.5( \pm 0.78)$ & $55.0( \pm 0.81)$ & 89.5 & 58.4 \\
\hline Field W1 & $4.32( \pm 0.06)$ & $47.5( \pm 0.50)$ & $49.1( \pm 0.58)$ & 96.6 & 50.8 \\
\hline Field W2 & $4.37( \pm 0.03)$ & $34.5( \pm 0.77)$ & $37.0( \pm 0.61)$ & 71.5 & 51.7 \\
\hline
\end{tabular}

(Hh) - hydrolytic acidity; (TEB) - total exchangeable bases; $(\mathrm{CEC})$ - cation exchange capacity $\mathrm{CEC}=\mathrm{TEB}+\mathrm{Hh}$; $(\mathrm{V})$ - bases saturation $\mathrm{V}=(\mathrm{TEB} / \mathrm{CEC}) \cdot 100 \%$

Table 3. Results of statistical analysis (Anova, the Tukey test)

\begin{tabular}{|l|c|c|c|}
\hline \multicolumn{1}{|c|}{ Parameters } & Forest soil & $\begin{array}{c}\text { Hunting } \\
\text { plots }\end{array}$ & $\begin{array}{c}\text { Significant } \\
\text { level }\end{array}$ \\
\hline $\mathrm{pH} \mathrm{KCl}$ & 3.48 & 4.12 & $\mathrm{P}=0.10$ \\
\hline $\mathrm{Hh}[\mathrm{mmol} / \mathrm{kg}]$ & 80.2 & 38.9 & $\mathrm{P}=0.018^{*}$ \\
\hline $\mathrm{TEB}[\mathrm{mmol} / \mathrm{kg}]$ & 41.4 & 52.9 & $\mathrm{P}=0.44$ \\
\hline $\mathrm{CEC}[\mathrm{mmol} / \mathrm{kg}]$ & 121.6 & 91.8 & $\mathrm{P}=0.16$ \\
\hline$(\mathrm{V})[\%]$ & 34.0 & 57.7 & $\mathrm{P}=0.07$ \\
\hline $\mathrm{K}_{2} \mathrm{O}[\mathrm{mg} / 100 \mathrm{~g}]$ & 10.6 & 17.3 & $\mathrm{P}=0.66$ \\
\hline $\mathrm{P}_{2} \mathrm{O}_{5}[\mathrm{mg} / 100 \mathrm{~g}]$ & 6.3 & 8.4 & $\mathrm{P}=0.70$ \\
\hline $\mathrm{Mg}[\mathrm{mg} / 100 \mathrm{~g}]$ & 2.4 & 2.9 & $\mathrm{P}=0.63$ \\
\hline $\mathrm{C}_{\text {org }}[\mathrm{g} / \mathrm{kg}]$ & 31.6 & 13.1 & $\mathrm{P}=0.054$ \\
\hline $\mathrm{N}_{\mathrm{T}}[\mathrm{g} / \mathrm{kg}]$ & 1.94 & 1.20 & $\mathrm{P}=0.31$ \\
\hline $\mathrm{C} / \mathrm{N}$ & 16.3 & 11.0 & $\mathrm{P}=0.035^{*}$ \\
\hline $\mathrm{CL}[\mathrm{g} / \mathrm{kg}]$ & 7.48 & 2.45 & $\mathrm{P}=0.029^{*}$ \\
\hline $\mathrm{C}_{\mathrm{NL}}[\mathrm{g} / \mathrm{kg}]$ & 24.1 & 10.6 & $\mathrm{P}=0.067$ \\
\hline $\mathrm{L}$ & 0.273 & 0.224 & $\mathrm{P}=0.34$ \\
\hline
\end{tabular}

*Significant differences

$\mathrm{Mg}$ in the soils of most cultivated plots (Table 4). Sienkiewicz et al. [2011] found that keeping soil as a bare field as well as leaving natural plants for several years resulted in the depletion of macronutrients in soil. During the decomposition of needle litter in forest soils, the chemical traits might change due to the release of chemical elements from or their immobilization. The amounts of phosphorus may increase during the initial stages of decomposition but $\mathrm{K}$ and $\mathrm{Mg}$ were released at the rates most similar to the organic matter weight loss [Staaf and Berg1982). Potassium and magnesium are essential nutrients for plants and are easily removed from decomposing litter in the forest ecosystems. The concentrations of $\mathrm{P}$ significantly increased during the decomposition of needle litter, while the concentrations of $\mathrm{K}$ decreased [Kainulainen and Holopainen 2002].
The decay rate of SOM in a natural forest is lower than in an agricultural field [Krishna and Mohan 2017]. Kramer et al. [2006] found that SOM increases the availability of nutrients and improves the fertilization efficiency due to its high cation exchange capacity that prevents the nutrient losses. Higher mean content of $\mathrm{C}_{\text {org }}$ (Table 5) was noted in the humus horizon of the soil under forests $(31.6 \mathrm{~g} / \mathrm{kg})$ compared with the arable horizon of hunting plots. Under the specific conditions found in the ectohumus of forest soils, an accumulation of organic remains occurred, which transformed into humus in the humification process [Krishna and Mohan 2017]. In general, the forest soils have most of SOM in upper soil horizons. After tillage organic matter is mixed in the topsoil. Different conditions occur in the arable horizon of cultivated soils in which mineral fertilisation or inadequate crop rotation can accelerate rate of the SOM mineralization [Murty et al. 2002). In such case, the advantage of that process over humification regularly decreases the content of humus in soil [Haynes 2005]. The results confirm the earlier studies that soil cultivation on hunting plots reduced the content of $\mathrm{C}_{\text {org }}$ and $\mathrm{N}_{\mathrm{T}}$ as well as the values of the $\mathrm{C}: \mathrm{N}$ ratio. It also confirms that in the soil of arable plots, the mineralization process was more intense [Kondratowicz-Maciejewska and Kobierski 2012].

It was demonstrated that only in two hunting plots (S2 and W1) the CMI accounted for more than $50 \%$ of the value of the reference soil (Table 5) and in the others - the value was lower than $30 \%$. The deteriorated carbon management in the soil of the Ap horizon of the cultivated plots is a consequence of the decrease in the total organic carbon content, as compared with its content in the A horizon of forest soils. 


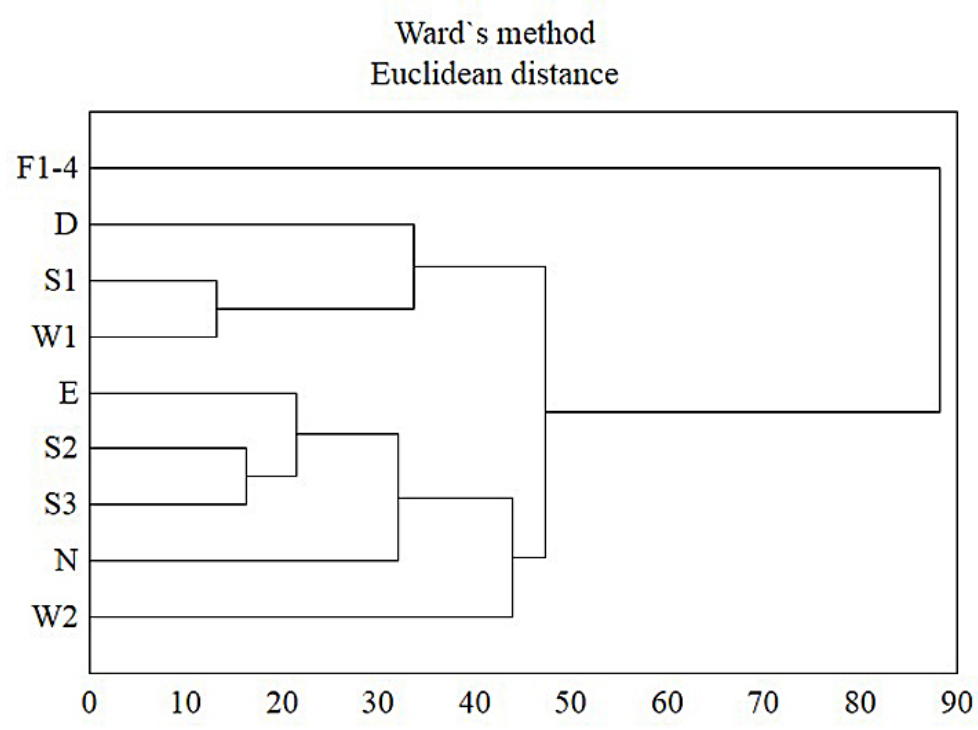

Fig. 1. The cluster analysis based on: content of sand, silt, clay, $\mathrm{pH}$, hydrolytic acidity, sum of base cations, cation exchange capacity, content of the plant-available forms of $\mathrm{K}, \mathrm{P}$ and $\mathrm{Mg}$

Table 4. Content of elements available to plants

\begin{tabular}{|l|c|c|c|}
\hline \multirow{2}{*}{ Sample } & $\mathrm{K}_{2} \mathrm{O}$ & $\mathrm{P}_{2} \mathrm{O}_{5}$ & $\mathrm{Mg}$ \\
\cline { 2 - 4 } & \multicolumn{3}{|c|}{$(\mathrm{mg} / 100 \mathrm{~g})$} \\
\hline Forests F1-4 & $10.6( \pm 0.21)$ & $6.3( \pm 0.21)$ & $2.4( \pm 0.26)$ \\
\hline Field D & $38.6( \pm 0.57)$ & $10.9( \pm 0.38)$ & $2.9( \pm 0.15)$ \\
\hline Field E & $11.3( \pm 0.15)$ & $5.9( \pm 0.06)$ & $3.4( \pm 0.35)$ \\
\hline Field N & $19.1( \pm 0.21)$ & $8.4( \pm 0.29)$ & $3.9( \pm 0.21)$ \\
\hline Field S1 & $7.02( \pm 0.04)$ & $5.6( \pm 0.30)$ & $1.9( \pm 0.21)$ \\
\hline Field S2 & $25.6( \pm 0.47)$ & $11.0( \pm 0.30)$ & $3.3( \pm 0.25)$ \\
\hline Field S3 & $12.2( \pm 0.21)$ & $9.4( \pm 0.29)$ & $2.9( \pm 0.30)$ \\
\hline Field W1 & $15.1( \pm 0.21)$ & $14.1( \pm 0.15)$ & $3.3( \pm 0.06)$ \\
\hline Field W2 & $9.4( \pm 0.42)$ & $2.1( \pm 0.21)$ & $1.9( \pm 0.38)$ \\
\hline
\end{tabular}

The degradation process of the pool of total organic carbon in the soil of the plots is reflected by low CPI values $(0.23-0.71)$ (Table 5). A decrease in the total content of organic carbon in the soils of cultivated plots even by $76.7 \%$ (W2) was observed, as compared with the forest soil. The lowest decrease of $\mathrm{C}_{\text {org }}$ was found for the plots $\mathrm{S} 2$ and $\mathrm{W} 1$, reaching $29.1 \%$ and $33.5 \%$, respectively. The results were confirmed by Sapek [2009] who claims that the forest soils, due to the specificity of use, are richer in organic carbon and introducing agrotechnical treatments results in a decrease in the humus content. The losses, however, can be limited and one can even increase the content of $\mathrm{C}_{\text {org }}$ and $\mathrm{N}_{\mathrm{T}}$ in soils by applying the adequate crop rotation and fertilisation [Cieścińska $2007 \mathrm{a}, \mathrm{b}$ ]. The mean contents of $\mathrm{C}_{\text {org }}$ and $\mathrm{N}_{\mathrm{T}}$ as well as the value of the $\mathrm{C}: \mathrm{N}$ ratio (Table 5) were higher for the soil samples under forest than on the arable plots. One can thus claim that in the soils of cultivated plots, the process of mineralization was most intensive. On the surface of hunting plots, on the other hand, the uncollected plant residue provides fresh organic material which, when introduced to soil, intensifies the mineralization of SOM. The LI values in the soils of cultivated plots were relatively high. As for three plots $(\mathrm{E}$, $\mathrm{S} 2$ and W1) the rate of the processes of mineralization of organic carbon (LI over 80) was similar to the soil material under forests (Table 5). Unlike the plots S2 and W1, where CMI assumed the highest value, plot E, despite a high LI value (84.2) showed a low CMI value (only 26.9). Such an unfavourable CMI value of the soil of that plot $\mathrm{E}$ was affected by a relatively low value of CPI (0.32). That soil must probably be characterised by favourable conditions for the mineralisation of organic carbon and reduction of the total organic carbon pool, which, as a result, definitely leads to the soil humus degradation. Besides, the soil samples from the Ap horizon of the hunting plots S2 and $\mathrm{W} 1$ showed similar properties of the content of $\mathrm{C}_{\mathrm{org}}, \mathrm{N}_{\mathrm{T}}$ and $\mathrm{C}_{\mathrm{L}}$ as compared with the averaged samples of A horizon under forests (Fig. 2).

\section{CONCLUSIONS}

Long-term tillage of soil in the hunting plots caused a decrease in the content of $\mathrm{C}_{\text {org }}$ as well as its labile and non-labile fractions. The values of Carbon Management Index indicate that 
Table 5. Parameters of organic matter and Carbon Management Index CMI of cultivated soils and uncultivated forest soils

\begin{tabular}{|c|c|c|c|c|c|c|c|c|c|}
\hline \multirow{2}{*}{ Sample } & $\mathrm{C}_{\text {org }}$ & $C_{L}$ & $\mathrm{C}_{\mathrm{NL}}$ & \multirow{2}{*}{ CPI } & \multirow{2}{*}{ L } & \multirow{2}{*}{ LI } & \multirow{2}{*}{$\mathrm{CMI}$} & $\mathrm{N}_{\mathrm{T}}$ & \multirow{2}{*}{$\mathrm{C}: \mathrm{N}$} \\
\hline & \multicolumn{3}{|c|}{$[\mathrm{g} / \mathrm{kg}]$} & & & & & {$[\mathrm{g} / \mathrm{kg}]$} & \\
\hline Forests F1-4 & $31.6( \pm 0.25)$ & $7.48( \pm 0.05)$ & 24.1 & - & 0.310 & - & - & $1.94( \pm 0.05)$ & 16.3 \\
\hline Field D & $12.2( \pm 0.52)$ & $1.83( \pm 0.05)$ & 10.4 & 0.39 & 0.176 & 56.8 & 22.1 & $1.08( \pm 0.03)$ & 11.3 \\
\hline Field E & $10.3( \pm 0.25)$ & $2.14( \pm 0.06)$ & 8.2 & 0.32 & 0.261 & 84.2 & 26.9 & $0.96( \pm 0.02)$ & 10.7 \\
\hline Field $\mathrm{N}$ & $11.4( \pm 0.21)$ & $1.79( \pm 0.10)$ & 9.6 & 0.36 & 0.186 & 60.0 & 21.6 & $1.17( \pm 0.01)$ & 9.7 \\
\hline Field S1 & $12.6( \pm 0.21)$ & $2.23( \pm 0.03)$ & 10.4 & 0.40 & 0.214 & 69.0 & 27,6 & $1.18( \pm 0.04)$ & 10.7 \\
\hline Field S2 & $22.4( \pm 0.42)$ & $4.67( \pm 0.06)$ & 17.7 & 0.71 & 0.264 & 85.2 & 60,5 & $1.86( \pm 0.04)$ & 12.0 \\
\hline Field S3 & $7.49( \pm 0.04)$ & $1.38( \pm 0.04)$ & 6.1 & 0.24 & 0.226 & 72.9 & 17.5 & $0.84( \pm 0.06)$ & 8.9 \\
\hline Field W1 & $21.0( \pm 0.40)$ & $4.30( \pm 0.07)$ & 16.7 & 0.66 & 0.257 & 82.9 & 54.7 & $1.94( \pm 0.04)$ & 10.8 \\
\hline Field W2 & $7.36( \pm 0.07)$ & $1.26( \pm 0.02)$ & 6.1 & 0.23 & 0.207 & 66.8 & 15.4 & $0.54( \pm 0.03)$ & 13.7 \\
\hline
\end{tabular}

$\mathrm{C}_{\text {org }}$ - total organic carbon; $\mathrm{N}_{\mathrm{T}}$ - total nitrogen; $\mathrm{C}_{\mathrm{L}}$ - labile fraction of carbon; $\mathrm{C}_{\mathrm{NL}}-$ non-labile carbon;

CPI - Carbon Pool Size Index; L - lability of carbon; LI - Lability Index

$\mathrm{C}_{\mathrm{NL}}=\mathrm{C}_{\text {org }}-\mathrm{C}_{\mathrm{L}} ; \mathrm{CMI}=\mathrm{CPI} \times \mathrm{LI} ; \mathrm{CPI}=\mathrm{C}_{\text {org }}$ sample $/ \mathrm{C}_{\text {org }}$ reference; $\mathrm{LI}=(\mathrm{L}$ sample $/ \mathrm{L}$ reference $) \times 100 ; \mathrm{L}=\mathrm{C}_{\mathrm{L}} / \mathrm{C}_{\mathrm{NL}}$

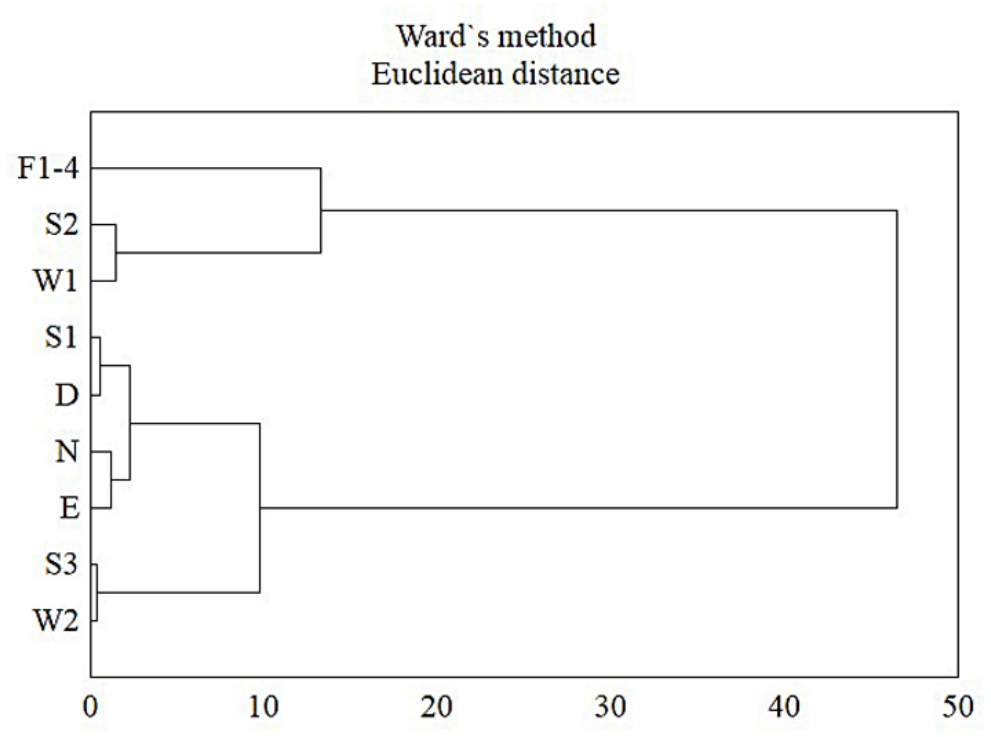

Fig. 2. The cluster analysis based on: $\mathrm{C}_{\text {org }}, \mathrm{N}_{\mathrm{T}}, \mathrm{C}_{\mathrm{L}}$

cultivation of plants, which enrich the feeding base of forest animals can impact on the dynamics of transformation and mineralisation rate of $\mathrm{C}_{\text {org }}$ in arable soils compared with forest soils. As a result low values of the CPI index indicate that the stock of organic carbon in hunting plots has decreased. Favourable conditions of the SOM decomposition in the arable Brunic Arenosols were observed from a definitely lower values of the $\mathrm{C}: \mathrm{N}$ ratio and a higher values of base saturation than in the reference forest soils. Tillage, placement, and incorporation of residue and nutrients contributed to the degradation of the pool of organic carbon in the sandy soils.

\section{REFERENCES}

1. Blair G.J., Blair N., Lefroy R.D.B., Conteh A., Hejko D. 1997. Relationships between KMnO4 oxidizable $\mathrm{C}$ and soil aggregate stability and the derivation of a carbon management index. in: Drozd J., Gonet S.S., Senesi N. Weber J. (Eds). The role of humic substances in the ecosystems and in environmental protection, 227-232.

2. Blair G.J., Lefroy R.D.B., Lisle L. 1995. Soil carbon fractions, based on their degree of oxidation and the development of a carbon management index. Australian Journal of Agricultural Research, 46: 1459-1466.

3. Cieścińska B. 2007a. Comparison of carbon management indexes assayed for soil under various crop 
rotation and fertilization systems. Humic Substances Ecosystems, 7: 45-49.

4. Cieścińska B. 2007b. Use of indices to evaluate the condition of organic matter of soils. Zeszyty Problomowe Postępu Nauk Rolniczych, 520: 587-592. (in Polish with English abstract).

5. Conteh A., Blair G.J., Lefroy R.D.B., Whitbread A. 1999. Labile organic carbon determined by permanganate oxidation and its relationships to other measurements of soil organic carbon. Humic Substances in the Environment, 1: 3-15.

6. Gałka B., Łabaz B. 2014. Skład frakcyjny materii organicznej powierzchniowych poziomów próchnicznych gleb leśnych Gór Stołowych. Sylwan, 158, 1: 18-25. (in Polish with English abstract).

7. Halpern M.T., Whalen J.K. Madramootoo C.A. 2010. Long-term tillage and residue management influences soil C and N dynamics. Soil Science Society of America Journal, 74: 1211-1217.

8. Haynes R.J. 2005. Labile organic matter fractions as central components of the quality of agricultural soils: an overview. Advances in Agronomy, 85, 221-268.

9. Kainulainen P., Holopainen J.K. 2002. Concentrations of secondary compounds in Scots pine needles at different stages of decomposition. Soil Biology and Biochemistry, 34,1: 37-42.

10. Kazlauskaite-Jadzevice A., Tripolskaja L. Volungevicius J., Baksiene E. 2019. Impact of land use change on organic carbon sequestration in Arenosol. Agricultural and Food Science, 28: 9-17.

11. Kondratowicz-Maciejewska K., Kobierski M. 2012. Effect of Brunic Arenosols use on selected physicochemical properties in organic matter. Soil Science Annual, 63,2: 19-24. (in Polish with English abstract).

12. Krishna M.P., Mohan M. 2017. Litter decomposition in forest ecosystems: a review. Energy, Ecology and Environment, 2: 236-249.

13. Lefroy R.D.B., Blair G.J., Strong W.M. 1993. Changes in soil organic matter with cropping as measured by organic carbon fraction and $13 \mathrm{C}$ natural isotope abundance. Plant and Soil, 155/156: 399-402.

14. Łoginow W., Wiśniewski W., Gonet S.S., Cieścińska B. 1987. Fractionation of organic carbon based on susceptibility to oxidation. Polish Journal of Soil Science, 20, 1: 47-52.
15. Murty D., Kirschbaum M.U.F., Mcmurtrie R.E., Mcgilvray H. 2002. Does conversion of forest to agricultural land change soil carbon and nitrogen? A review of the literature. Global Change Biology, 8: 105-123.

16. Parzych A., Mochnacký S., Sobisz Z.1, Kurhaluk N., Polláková N. 2017. Accumulation of heavy metals in needles and bark of Pinus species. Folia Forestalia Polonica. Serie A. Forestry, 59, 1: 34-44.

17. Sapek B. 2009. Preventing losses and organic carbon sequestration in meadow soils. Inżynieria. Ekologiczna, 21: 48-59. (in Polish with English abstract).

18. Sienkiewicz S., Żarczyński P., Krzebietke S. 2011. Effect of land use of fields excluded from cultivationon soil content of available nutrients. Journal of Elementology, 16, 1: 75-84.

19. Skjemstad J. O., Swift R.S. McGowan J.A. 2006. Comparison of the particulate organic carbon and permanganate oxidation methods for estimating labile soil organic carbon. Australian Journal of Soil Research, 44, 3: 255-263.

20. Staaf H, Berg B. 1982. Accumulation and release of plant nutrients in decomposing scots pine needle litter. Long-term decomposition in a Scots pine forest II. Canadian Journal of Botany, 60: 1561-1568.

21. Stanek-Tarkowska J., Czyż E.A., Dexter A.R, Sławiński C. 2018. Effects of reduced and traditional tillage on soil properties and diversity of diatoms under winter wheat. International Agrophysics, 32, 403-409.

22. Strączyńska S., Strączyński S., Cieścińska B., Gwiżdż M. 2009. Properties of organic matter in the surface horizon of anthropogenic soils in the region of Bełchatów. Roczniki Gleboznawcze, Soil Science Annual, 60, 3: 139-144. (in Polish with English abstract).

23. Szombathova N. 1999. Susceptibility to oxidation with $\mathrm{KMnO} 4$ solutions of organic matter in soils under various farming systems. Humic Substances Ecosystems, 3: 105-109.

24. van Eerd L.L., Congreves K.A., Hayes A., Verhallen A., Hooker D.C. 2014. Long-term tillage and crop rotation effects on soil quality, organic carbon, and total nitrogen. Canadian Journal of Soil Science, 94,3: 303-315.

25. Vaseneva V.I., Stoorvogela J.J., Vasenev I.I. 2013. Urban soil organic carbon and its spatial heterogeneity in comparison with natural and agricultural areas in the Moscow region. Catena, 107, 96-102. 